\title{
COMPARATIVE STUDY OF WORD-ORDER PATTERNS OF SIMPLE SENTENCES IN ENGLISH AND ARABIC
}

\author{
Mounya Souadkia \\ RUDN University \\ 6, Miklukho-Maklay str., Moscow,Russia, 117198
}

\begin{abstract}
It is sociolinguistically acknowledged that humans are uniquely distinct from other living species due to the fact that they communicate with one another through the use of a particular human language. Furthermore, the number of human languages that exist worldwide is huge. Unsurprisingly, languages can be similar or different form one another as well as the main aims of each language. Standard Arabic and Standard English languages, for instance, are distinct from one another but at the same time they are alike. Explicitly, the two languages are originally different from one another (one Semitic while the other German) but they do share at least some general linguistic features at all levels: phonological, morphological, syntactic, semantic, and pragmatics' level. In this research paper, fields which are closely connected to the linguistic analysis and comparison of languages known as Contrastive Analysis, Comparative Linguistics and Universal Grammar will be referred to in comparing between Standard Arabic and Standard English in terms of their word-order patterns of simple sentences.
\end{abstract}

Key words: word-order patterns, simple sentences, Standard Arabic (SA), Standard English (SE), Comparative study, Contrastive analysis hypothesis, Universal Grammar

\section{INTRODUCTION}

Historically, linguists worldwide have made many attempts trying to identify one language as the source of all languages. Furthermore, their investigations intended to formulate or map world languages, to find out what makes a language similar or different from another language, and how to explain these differences. On the one hand, linguists lead by Chomsky, have attempted to examine the common features/aspects of all the languages of the world. Specifically, his theory is known as Universal Grammar (UG). On the other hand, however, other linguists have preferred to investigate languages via the similarities they mutually share together. Essentially, this is called Comparative Linguistics (CL); researchers in this field are concerned with comparing two or more languages, dialects, etc., to discover similarities between/among them.

Moreover, another approach has appeared in the early 1940s and prospered in the 1960 and over, known as Contrastive Analysis (CA) or as Contrastive Linguistics [Lightbown 2006: https://ru.scribd.com/doc/47136503/Lightbown-Spada-2006]. The theory of Contrastive Analysis also identified as Lado's Contrastive Analysis Hypothesis (CAH) was first introduced in R. Lado's Linguistics Across Cultures (1957). In the first chapter of his book, Lado states: "In the comparison between native and foreign language lies the key to ease or difficulty in foreign language learning... those elements that are similar 
to (the learner's) native language will be simple for him, and those elements that are different will be difficult [see: Yang, 1992].

From the quote stated above, it is clear that contrastivists believe that contrasting and analyzing two languages must be done through concentrating on the differences between them that are the cause of the difficulty to learn a second language.

One of the most important areas of languages study and analysis is through examining and investigating word order patterns and/or types that exist in simple sentence structures. Consequently, in linguistics word order is referred to as the study of the order of the syntactic constituents of a language. To simply put it, word order is the order of subject $(\mathrm{S})$, verb $(\mathrm{V})$ and object $(\mathrm{O})$ in a sentence. The primary word orders that are of interest are the constituent order of a clause - the relative order of subject, object, and verb; the order of modifiers in a noun phrase; and the order of adverbials. For example, in English the word order of a typical sentence is Subject-Verb-Object (SVO). To English speakers this seems obviously the only logical arrangement. Nonetheless, a lot of languages have a different word order, such as Arabic which is mainly recognized as being VSO (Verb-Subject-Object), with an alternative SVO order.

Hence, mainly this work is a contrastive study of the simple sentence structure of both standard Arabic (SA) and Standard English (SE), where in both languages are introduced in brief, their simple sentence structures are described, and then they are compared by examples taken from data collected at random. More outstandingly, this research paper will cover the area concerning the word order of both simple sentence patterns of the two languages and investigate the validity of the claim that (SA) is (VSO) and $(\mathrm{SE})$ is $(\mathrm{SVO})$.

\section{LITERATURE SURVEY: DESCRIPTION STAGE}

Arabic and English are two major languages in the world. On the one hand, in the case of Arabic, it is possibly due to the fact that a large number of the population of the world speaks it, however more importantly for being the language of Islam. English, on the other hand, nowadays is the language of international communication or more specifically the Lingua Franca, also the language of technology and academic and higher education even in some Arab Countries and other foreign countries in Europe and many regions and countries in this world. Both Standard Arabic and Standard English are two of the official languages declared by the United Nations.

The Arabic language is divided into three types: Classical Arabic, Standard Arabic and Spoken Arabic. In short, classical Arabic is usually referred to the language used before Islam, language of poetry, literature and golden ages of Islam and Arabic Sciences. Afterward, precisely after the European Renaissance, a new age has appeared along with a new version of Arabic which has been called Standard Arabic or Modern Standard Arabic. Moreover, what has been called as Classical Arabic is being only used for the Holy Quran and ancient Arabic books. Similarly, nowadays Standard Arabic language is only used in formal states, academic publications, educational materials such as books or articles, news and broadcasting channels, etc, [Owens, 2006, as cited in Saleh Alduais, 2012]. In the Arab world, there are a huge number of dialects/varieties which 
are in each country. For instance, Yemen's Arabic language is to some extent different from the Saudi's Arabia kingdom Arabic language. Yet, these two Arabic dialects are to a huge extent different from the Moroccan and Algerian Arabic dialects, for this reason, Standard Arabic is being used here as the data of this contrastive study.

The English language is used as a native language for about three hundred million people in countries such as United Kingdom, United States of America, Australia, Canada and many others. English is now widely used, due to the fact that a huge number of learners seek to acquire it as either a foreign or second language because they are fully aware that has became of a great importance in the world. Similar to Arabic, there are some dialects in English but the number is less than those of Arabic, also the varieties are similar to one another.

\section{THEORETICAL COMPARISON AND CONTRAST}

The first difference between (SA) and (SE) is that Arabic is originally Semitic (belonging to the Asian language family) whereas English is Germanic (it belongs to the European language family). Additionally, Arabic spread due to religious reasons, that is to say, Muslims have to learn the Arabic language in order to be able to read the Holy Quran. While English became popular because of business, academic, educational and economic reasons. Another difference between the two languages is in their writing system and the number of letters they have. While Arabic is a right to left in its writing system, English is a left to right in its own. Moreover, Arabic has twenty eight letters and English has twenty six [Ibrahim, 2000, as cited in Saleh Alduais, 2012].

Standard Arabic and Standard English are also phonetically, phonologically, semantically, morphologically, pragmatically and syntactically different. Phonetically, Standard Arabic has some more places and manners of articulations which are not required in Standard English, those such as Velarized and pharyngalized sounds. In phonology, in English vowels and basic and more in number compared to Arabic which are three in total. In addition to that, vowels in the Arabic language do not appear in written words as in the English language, but they can be identified through the use of case-markers or diacritics (in nominative, accusative, and genitive cases). From a morphological point view, Standard Arabic is more inflectional than Standard English. Semantically, there are words which are similar in the two languages and may have more than one meaning or words in one language but not the other, each to be used in a particular situation. For example, the word (Maktabah), in Arabic the word refers to all (bookshop, bookstore, library, and stationary), in English. Sometimes, in the one language, words do not have their equivalents in the other language. Pragmatically, a particular utterance or word uttered by a speaker of Arabic would carry a meaning he/she wants to convey which would be different or meaningless when heard by speakers of English. Syntactically, English and Arabic are to a great extent different from one another, some syntactic differences include sentences' structure, word-order, subject-verb agreement and others. In short, Standard Arabic is a free-word-order (FWO) which means that its sentence's structure can be both $(\mathrm{S}+\mathrm{V}+\mathrm{O})$ or $(\mathrm{V}+\mathrm{S}+\mathrm{O})$, as a statement, while Standard English is a fixed-word-order (FIWO), i.e., its sentence's structure can be only $(\mathrm{S}+\mathrm{V}+\mathrm{O})$ [Haywood, 1965, as cited in Saleh Alduais, 2012]. 


\section{SIMPLE SENTENCE STRUCTURE}

In grammar, a sentence is considered the largest unit in any written language. However, in spoken language, it is not clear what could be a sentence and what could not be a sentence. When defining a sentence, Leech argues "in writing, sentences are marked by beginning with a capital letter and ending with a full stop (.), question mark (?), or exclamation mark (!), in spoken language, the definition is problematic". Furthermore, a sentence can be in various forms and types in any language, these forms are as follows: statements, interrogative, imperative and exclamation. Therefore, Standard Arabic and Standard English may contain similar simple sentence structures, and may also contain different ones.

A simple sentence in English can be defined as "a complete unit of meaning which contains a subject and a verb, followed, if necessary, by other words which make up the meaning" [Alexander: 1990, p. 4, as cited in Saleh Alduais, 2012]. Additionally, the English language is considered to have a fixed-word-order (FIWO), which precisely requires a subject (Noun Phrase, NP) to come first, obliged to be followed by a verb (Verb Phrase, VP) and other elements of the sentence depending greatly on the type of the verb (VP) used in the sentence.

On the other hand, the case is different in Standard Arabic concerning simple sentence structure. To simply put it, the structure of simple sentence structure in (SA) in not complex, there are two main sentence structures often referred to as the nominal and the verbal sentences. Clearly, a nominal sentence is the one that begins with a noun (i.e. Noun Phrase), while a verbal sentence is the one that begins with a verb (i.e. Verb Phrase).

\section{COMPARISON AND CONTRAST}

As it has been pointed out earlier in the above lines, Standard Arabic is a free-wordorder language, while Standard English has a fixed-word-order system of simple sentence structure. It is of great importance to discuss and explain in more details how and why Arabic is a FWO whereas English is FIWO, and what is allowed and what is not allowed in building simple sentences in both (SA) and (SE) languages.

A basic simple sentence in English is one which contains a subject (NP) and an intransitive verb, that is ( $\mathrm{S}=\mathrm{NP}+\mathrm{VP}),($ Ahmed, 2008) and (Patzold, 1985) (as cited in Saleh Alduais, 2012).

For example: The lesson started.

$\mathrm{S}=$ (The lesson started.)

$\mathrm{S}=(\mathrm{NP}+\mathrm{VP})$

$\mathrm{NP}=($ Det $+\mathrm{N})$

Det $=($ the $)$

$\mathrm{N}=$ (lesson)

$\mathrm{VP}=($ In. V)

$\mathrm{VP}=($ started $)$

Other patterns of the simple sentence in English could be as the follows:

(NP+ VP+ Comp):

A comp can be (DO), (IO), (DO+IO), (DO+SA), (DO+PC); 
Or it can be:

(NP+ VP+ Comp);

The (VP) here will be (a copula) and the (NP) will be (SA);

Or the (VP) is (a non-transitive verb) and the (NP) is (a PC).

In the English language the (NP) is the basic element of the simple sentence and cannot be changed unless the form of the sentence is changes to a question, imperative, etc. additionally, what comes after the NP is put obligatory, it is the VP; without VP, the sentence cannot exist. Finally, what follows the (VP) is greatly dependent on the type of the verb used whether auxiliary or lexical, and if it is lexical it can be a non-complement verb (intransitive) or a complement verb (non-transitive, transitive), etc.

Contrastingly, the simple sentence structure in Arabic is divided into four types: nominal sentences vs. verbal sentences and equational (or non-verbal) sentences vs. verbal sentences. Firstly, nominal sentences vs. verbal sentences: a nominal sentence is a sentence that begins with a noun (NP) followed by a verb (VP) and a complement. A verbal sentence is a sentence which starts with a verb (VP), followed by a subject (NP) and ends with a complement depending on the type of the verb. Here is the example:

1. الغرض الرئيسي كان غرضا سياسيا. Ialgharad alrrayiysi kanaa gharadaan siasiaan The translation is as follows: The main purpose was a political purpose.

The nature of the free-word-order system of the Arabic language allows us to move the verb (underlined) in the sentence above which in this case is (kanaa = was), to the beginning of the sentence without changing the meaning of it and it stays grammatically acceptable. As a consequence, the nominal sentence will then become a verbal one. The following sentence shows the change that can be done:

2. ان الغرض الرئيسي غرضا سياسيا. Kanaa algharad alrrayiysi gharadaan siasiaan

The translation in English is the same for both nominal and verbal sentences in Arabic. Furthermore, in (SA) a verbal sentence can also be uttered into a nominal sentence without adding or changing basic elements, for instance:

3. Maratha aleibno al'aba/ ورث الابن الأب.

In English the sentence means: The son inherited the father.

Thus, the sentence above can be changed into the following nominal sentence:

4. الابنورث الأب. Ialeibno waratha al'abal

In English it is the same: The son inherited the father.

Thus, one can conclude that (SE) does not allow this kind of structure in its system. Whereas, (SA) does allow this kind of structure in its system, that is, it can be either $(\mathrm{NP}+\mathrm{VP}+\mathrm{Comp} / \phi)$ or $(\mathrm{VP}+\mathrm{NP}+\mathrm{Comp} / \phi)$.However, there are other cases in the Arabic language where it not allowed changing a sentence from one structure to another unless following some rules and restrictions in order to keep the sentence meaningful, well-formed and grammatically acceptable.

For a better understanding, here are some examples:

5. ام الأساتذة تقدير اللعالم. /Kaama al'assaatidhato takdiiran lileaalemy

The English equivalent: The professors stood up appreciatively for the scientist. 
The sentence 5 is verbal since it starts with the verb (VP) (kaama = stood up), then comes the subject (NP) (al'assaatidhato = professors), and finally ends with the complement (Comp) (takdiiran lileaalemy = appreciatively for the scientist). For this sentence to be reversed into a non-verbal sentence one has to take into consideration the agreement between the subject (NP) (people) and the verb (VP) (stood up). If this agreement is not taken into focus, and the change is being made, it will absolutely result in producing a meaningless, ill-formed and grammatically unacceptable sentence from the Standard Arabic point of view. Consider the same sentence where changes are made without any consideration to the subject (NP) and the verb (VP):

6. /Al'assatidhato kaama takdiiran lileaalemy/ الأساتذة قام تقدير ا للعالم

When the sentence 5 was changed, it became unaccepted because it is ungrammatical and ill-formed (sentence 6). The verb here doesn't agree with the subject. Explicitly, the subject is plural but the verb is not (even though when the structure of the sentence 5 was not changed, this did not matter much because the verb was put first, which is the case in sentence 6). In the sentence the subject is plural so this directly means that the verb must also be in the plural. The mark of plural must be added to the verb in order to formulate a plural verb. Moreover, the gender of the subject must also be taken into consideration before forming the plural verb. In addition to that, the dual pronoun that exist in (SA) and does not in (SE) must be taken into account and which also differ in terms of gender, i.e. it can be masculine or feminine. Significantly, there are also the cases: whether it is genitive, accusative or nominative in order to add the mark of what and which. The following structures show the applying of these rules according to the Arabic language:

7. الأساتذة قاموا تقدير اللعالم. Al'assaatidhato kaamoo takdiiran lileaalemy

All professors stood up appreciatively for the scientist (Masculine).

8. الأساتذة قمن تقدير ا للعالم. Al'assaatidhato komna takdiiran lileaalemy

All professors stood up appreciatively for the scientist (Feminine).

9. الأستاذان قاما تقدير اللعالم. Al'ostadhaany kaamaa takdiiran lileaalemy

The two professors stood up appreciatively for the scientist (Masculine).

10. /Al'ostadhataany kaamataa takdiiran lileaalemy/. الأستاذتان قامتا تقدير ال للعالم

The two professors stood up appreciatively for the scientist (Feminine).

11. /Kaama al'ostadhaany takdiiran lileaalemy/ قام الأستاذان تقدير اللعالم

Both professors stood up appreciatively for the scientist (Masculine).

12. /Kaamataa al'ostadhataany takdiiran lileaalemy/ قامتا الأستاذتان تقدير اللعالم) Both professors stood up appreciatively for the scientist (Feminine).

13. /Komna al'assaatidhato takdiiran lilealemy/ قمن الأساتذة تقدير اللعالم (Ft) Professors stood up appreciatively for the scientist (Feminine).

14. /Kaama al'ostaadho takdiiran lilealemy/ قام الأستاذ تقدير اللعالم) The professor stood up appreciatively for the scientist (Masculine

15. IAl'ostaadho kaama takdiiran lilealemy/ الأستاذ قام تقدير اللعالم The professor stood up appreciatively for the scientist. (Masculine)

16. /Kaamati al'ostaadhato takdiiran lilealemy/ قامت الأستاذة تقدير ا للعالم The professor stood up appreciatively for the scientist (Feminine). 


\section{7. /Al'ostaadhato kaamat takdiiran lilealemy/ الأستاذة قامت تقدير ا للعالم (Faph}

The professor stood up appreciatively for the scientist (Feminine).

Secondly, equational (or non-verbal) sentences vs. verbal sentences: essentially and as mentioned above, this type of sentences appears without a verb namely in the case of present simple tense when the sentences have only two elements (NP + Comp) known in the Standard Arabic as (mubtad'a and khabbar), e.g.:

18. /Al'loghawiat hiya al'diraasa al'eilmiya lil'loghat/ اللغويات هي الدر اسة العلمية لللغات The sentence means: Linguistics is the scientific study of language.

19. / Al'insaan kaaen hay/ الإنسان كائن حي.

The English equivalent: The human being is a living creature.

The two examples show what is referred to in Standard Arabic as non-verbal (or equational) sentences. In this type of sentences, no verb can be found and they can appear as the verb (to be) only when translated into the English language. Nevertheless, the verbs can also come to being when attempting to alter the sentences into verbal ones, but changing them is not permitted due to the fact that there are logically no verbs that can be moved around to make up verbal sentences. However, a lot of Arabic speakers especially writers would often use some other words that can function as verbs, but in translation one can figure out that such alternatives do not influence the preceding translation. In the following examples, sentences 18 and 19 of the examples mentioned above are altered from non-verbal sentences into verbal ones to give us these:

\section{0. /Yuetabaro al'insaan kaaen hay/ يعتبر الإنسان كائن حي}

In this case, the English translation is the same and does not require any change: the human being is a living creature. Or it can be as follows: the human being is considered a living creature.

\section{1. /Toetabaro al'loghawiat hiya al'diraasa al'eilmiya lil'loghat/ تعتبر اللغويات هي الدراسة العلمية لللغات.}

In such a case, the structure of the sentence becomes an ill-formed one when inserting this kind of verb. For this sentence to be acceptable, one more change must be done; the deletion of another word (in the case above the word "hiya" must be omitted). The sentence becomes:

22. /Toetabaro al'loghawiat al'diraasa al'eilmiya lil'loghat/ تعنبر اللغويات الدر اسة العلمية للغات.

The English translation would also be the same as the previous one: linguistics is the scientific study of languages. Or it can be literary translated into: linguistics is considered to be the scientific study of languages.

\section{CONCLUSION}

To sum it up, the analytic study proved that Standard Arabic's sentence structure is a VP $+\mathrm{NP}+\ldots$ while Standard English's is an NP $+\mathrm{VP}+\ldots$ through using the Contrastive analysis. Moreover, Lado's Contrastive Analysis hypothesis is highly helpful in the teaching-learning process, as well as translation and syllabuses' plan. 
In the end, it is now well-known that Standard Arabic and Standard English are to a great extent different to one another. But at the same time they can somehow be similar; different in that English's simple sentence structure in the form of a statement can never start with a verb (VP), and similar in that both languages have simple sentence structures following the order $(\mathrm{NP}+\mathrm{VP}+\ldots)$.

(C) Mounya Souadikia

Дата поступления: 20.12.2016

Дата принятия к печати: 25.01.2017

\title{
REFERENCES
}

1. Contrastive Analysis. Wikipedia, the Free Encyclopedia. URL: https://en.wikipedia.org/wiki/ Contrastive_analysis (accessed: 24 January 2017).

2. Lightbown, P. \& Spada, M. (2006). How languages are learned. URL: https://ru.scribd.com/ doc/47136503/Lightbown-Spada-2006 (accessed: 19.12.2016).

3. Saleh Alduais, A. (2012). Simple Sentence Structure of Standard Arabic Language and Standard English Language: A Contrastive Study. International Journal of Linguistics. URL: http://www.macrothink.org/journal/index.php/ijl/article/viewFile/2621/pdf (accessed 23 January 2017).

4. Word Order. Wikipedia, the Free Encyclopedia. URL: https://en.wikipedia.org/wiki/Word_order (accessed: 24 January 2017).

5. Yang, B. (1992). A Review of the Contrastive Analysis Hypothesis. URL: http://fonetiks.info/ bgyang/db/92cah.pdf (accessed: 23 January 2017).

\section{СОПОСТАВИТЕЛЬНОЕ ИССЛЕДОВАНИЕ МОДЕЛЕЙ ПОРЯДКА СЛОВ В ПРОСТОМ ПРЕДЛОЖЕНИИ В АНГЛИЙСКОМ И АРАБСКОМ ЯЗЫКАХ}

\author{
Муния Суадкиа \\ Российский университет дружбы народов \\ ул. Миклухо-Маклая, 6, Москва, Россия, 117198 \\ mounya.sdkia@gmail.com
}

Социолингвистика исходит из того, что люди явно отличаются от всех других живых существ, потому что они общаются друг с другом используя такой инструмент, как человеческий язык. Более того, число человеческих языков огромно, но в них обнаруживаются не только различия, но и сходства. Standard Arabic и Standard English, например, в чем-то сходны, а в чем-то различны. Внешне они различны уже потому, что принадлежат различным языковым семьям и группам, но на языковых уровнях устанавливаются общности: фонологическая, морфологическая, синтаксическая, семантическая и прагматическая. В этом исследовании языковые единицы - простые предложения Standard Arabic и Standard English рассматриваются через призму контрастивного анализа, сопоставительной лингвистики и языковых грамматических универсалий в аспекте порядка слов в простом предложении.

Ключевые слова: модели словопорядка, простое предложение, Standard Arabic (SA), Standard English (SE), сопоставительное исследование, контрастивный анализ, постулаты универсальной грамматики 


\section{БИБЛИОГРАФИЧЕСКИЙ СПИСОК}

1. Contrastive Analysis. Wikipedia, the Free Encyclopedia. Режим доступа: https:/en.wikipedia.org/ wiki/Contrastive_analysis (Дата обращения: 24 January 2017).

2. Lightbown P., Spada M. (2006). How languages are learned. Режим доступа: https://ru.scribd.com/doc/47136503/Lightbown-Spada-2006 (accessed: 19.12.2016).

3. Saleh Alduais A. (2012). Simple Sentence Structure of Standard Arabic Language and Standard English Language: A Contrastive Study. International Journal of Linguistics. Режим доступа: http://www.macrothink.org/journal/index.php/ijl/article/viewFile/2621/pdf (Дата обращения: 23 January 2017).

4. Word Order. Wikipedia, the Free Encyclopedia. URL: https://en.wikipedia.org/wiki/Word order (Дата обращения: 24 January 2017).

5. Yang B. (1992). A Review of the Contrastive Analysis Hypothesis. Режим доступа: http://fonetiks.info/bgyang/db/92cah.pdf (Дата обращения: 23 January 2017).

\section{Сведения об авторе:}

Муния Суадкиа - магистрант кафедры общего и русского языкознания филологического факультета РУДН; e-mail: mounya.sdkia@gmail.com

\section{Bio Note:}

Mounya Souadkia - Graduate student at Department of General and Russian Linguistics at RUDN University; e-mail: mounya.sdkia@gmail.com 